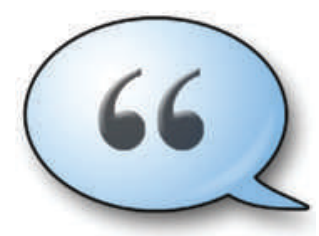

HAVE YOUR SAY

Comment on any of our News stories, online.

www.nature.com/news

\title{
Iranian academics fear more killings
}

Iran's scientific community is reeling after the assassination on 12 January of Masoud Alimohammadi, a particle physicist at the University of Tehran.

Alimohammadi was killed by a bomb as he got into his car to go to work. "Everyone is worried that this may be only the start, and that there may be more killings of academics to come," one researcher says.

Nature interviewed half a dozen scientists in Iran who knew Alimohammadi, all of whom requested anonymity. They are mystified as to why he was singled out. "I could expect that some influential political figure be assassinated, but not him," says one. Like many intellectuals in Iran, he was politically engaged, but far from being a political activist, the researchers say.

Iran's President Mahmoud Ahmadinejad and supreme leader Ayatollah Ali Khamenei have said that the killing was perpetrated by the country's "enemies" and was designed to hamper its scientific and technological progress. State media portrayed Alimohammadi as a "martyr" (pictured) and a "committed revolutionary professor".

Scientists in Iran hotly contest the official picture of Alimohammadi as a supporter of the Ahmadinejad regime. They say that he opposed both the current regime and the violent crackdown on protests that followed the disputed presidential elections last June. They also question the regime's implication that Alimohammadi was involved in Iran's nuclear programme, making him a target.

Alimohammadi supported the 1979

Islamic Revolution from the outset and had links in the past with the Islamic Revolutionary Guard Corps. But he opposed the hardline crackdown on student demonstrations in 1999. Last year, he was among hundreds of academics who signed a petition endorsing Mir Hossein Mousavi, the reformist presidential candidate.

Alimohammadi was also an organizer and first signatory of a 4 January letter by 88 academics at Tehran University to Ayatollah Khamenei, protesting against the regime's post-election repression and attacks on universities and students. Friends say that he did not endorse overthrow of the regime, but was "keen to find solutions for a way out of the crisis".

The scientists also say that, to their knowledge, Alimohammadi had nothing to do with Iran's nuclear efforts or any military programme. Although the regime last week

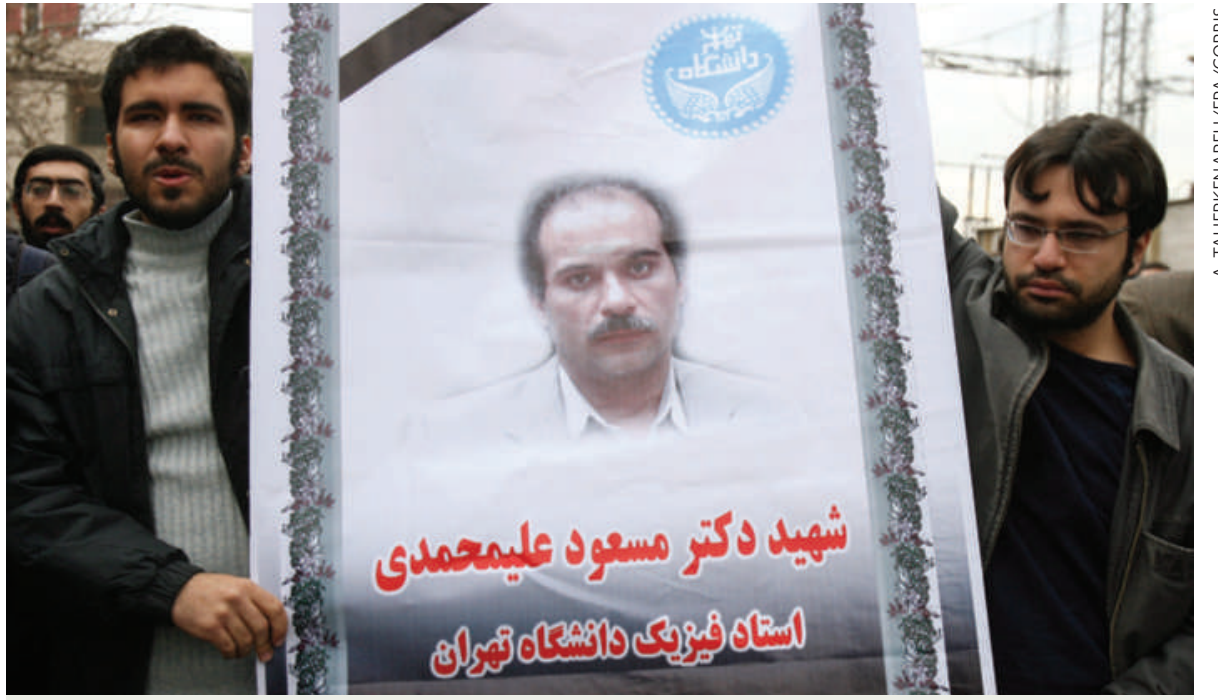

\section{Physicist was part of 'science for peace' project}

\author{
Masoud Alimohammadi \\ was one of Iran's two official \\ representatives on the board \\ of the Middle East's first \\ synchrotron facility, in Alaan, \\ Jordan. SESAME (Synchrotron- \\ light for Experimental Science \\ and Applications in the \\ Middle East) opened its doors \\ in November 2008, as a \\ collaborative effort to promote \\ peace through international \\ scientific cooperation. \\ Moshe Paz-Pasternak, \\ a physicist at Tel Aviv \\ University in Israel, says that \\ Alimohammadi showed
}

\author{
enthusiasm for SESAME \\ "from the first day" he \\ joined in summer 2008. His \\ participation in a project with \\ the Iranian regime's sworn \\ enemy Israel has prompted \\ speculation that this might \\ be linked to his assassination. \\ But SESAME board president \\ Christopher Llewellyn-Smith \\ dismisses the possibility. "I \\ can't conceive of any way in \\ which his death could possibly \\ be related to his involvement \\ in SESAME," he says. "I \\ was deeply shocked by the \\ assassination."
}

"It was very sad news," adds Tarek Hussein, president of Egypt's Academy of Scientific Research and Technology in Cairo. "In discussions at SESAME meetings, he and I shared a vision that science and technology is a common language for peace and prosperity, independent of politics, religion or gender." He says: "On behalf of the scientific community, we condemn this crime, and send our condolences to all the Iranian people and in particular to his family." described him as a nuclear scientist, he was a theoretical particle physicist; his $\mathrm{PhD}$ was on string theory, and he then moved on to the quantum effects of gravity and gauge theories, and more recently to research on dark energy and modified Newtonian dynamics.

"I can see no reason why or how Iran's military or nuclear programmes could benefit from Alimohammadi's expertise," says Moshe Paz-Pasternak, a physicist at Tel Aviv University in Israel who worked with Alimohammadi on the Middle East synchrotron SESAME (see 'Physicist was part of 'science for peace' project').

All of which leaves the killer's identity and motives a mystery. The regime has blamed Israel, the United States and "their lackeys", as well as various dissident groups. Others speculate that hardliners in the regime itself might have staged the killing as a warning to opposition supporters.

"If Alimohammadi was murdered by hardliners, then the message would be clear: that they are willing even to assassinate well-known and well-respected academics," says materials scientist Muhammad Sahimi of the University of Southern California in Los Angeles, "and that other academics must think twice before they participate in political activities to support Mousavi".

Many Iranian researchers say they would like the international scientific community to speak out and condemn the assassination. Declan Butler 